\title{
The illegal market in tiger parts in northern Sumatra, Indonesia
}

\author{
Campbell Plowden and David Bowles
}

The Sumatran tiger is the only one of three original subspecies of tigers that survives in Indonesia today. Its wild population, estimated to be 400-650 animals, has progressively diminished because of habitat destruction, poaching and the removal of tigers involved in conflicts with local farmers. This paper presents previously undocumented information on the market in tiger products. It shows that, while no documentation of intentional tiger poaching to meet an international demand for tiger bones was recorded, the domestic demand for tiger bones, teeth and claws is still a potential threat to the future survival of this subspecies. In addition to continuing work to protect the integrity of tiger habitat in Sumatra, enforcement actions are required to prevent the domestic market for tiger parts increasing the threats to this subspecies and to ensure its conservation.

\section{Introduction}

Three of the eight subspecies of tiger Panthera tigris formerly inhabited the Indonesian archipelago. By 1972 both the Bali tiger P. $t$. balica and Javan tiger $P$. t. sondaica were reported to be extinct, leaving only the Sumatran tiger $P$. t. sumatrae, whose range historically covered all Sumatra (Tilson et al., 1994). Habitat destruction, loss of wild prey, hunting for the trade in skins and bones, and the authorized removal of 'problem animals' involved in human conflicts, have all contributed to the depletion of Sumatran tigers in the wild, confining it to remnant isolated populations (Santiapillai and Ramono, 1987; Tilson et al., 1994). In the 1970s and 1980s, the Sumatran tiger population was estimated to be $600-1000$ animals (Borner, 1978; Santiapillai and Ramono, 1993), but by 1993 Mills and Jackson (1994) reported that the maximum population was probably closer to 650 , although there is no accurate information on the trends or status of the population for the last 5 years.

National legislation to protect the Sumatran tiger was first passed in 1972 and updated in 1990 with the passage of the Act of the Republic of Indonesia on Conservation of
Living Resources and Ecosystems, also known as Conservation Act (no. 5). This affords full protection to the subspecies. In 1992 the Indonesian Ministry of Forestry further strengthened enforcement of its domestic law by requiring people holding tiger trophies, mounts or other body parts to obtain permits. As a result of this one-time amnesty,1081 mounted tiger permits were issued (WWF Indonesia, 1992).

The major threats to the future of the tiger include trophy hunting, the use of poison to kill 'problem animals' by farmers, and the use of bones for the Traditional Chinese Medicine market, where they are used as cures for rheumatism and other ailments (Mills and Jackson, 1994). In spite of numerous anecdotal accounts of tiger poaching in Sumatra (e.g. Tilson and Traylor-Holzer, 1994), no previous study has adequately described how bones or other products taken from these animals have been commercialized in domestic or international markets, nor the extent of this trade. The purpose of this study was to provide this information and evaluate the extent and nature of the illegal hunting of tigers and the commercialization of tiger products both within and from Sumatra. 


\section{Methods}

The research for this study was completed during March and April 1995. A covert investigation was conducted into the availability of tiger products in northern Sumatra, particularly around the city of Medan. This area was chosen because of the presence of a large Chinese community in Medan and the existence of a large population of tigers in the nearby Gunung Leuser National Park. The principal investigator, a Caucasian who spoke Bahasa Indonesian, used the cover of a potential buyer of traditional medicines interested in procuring tiger bone for an Asian customer. An Indonesian expert in the jewellery trade accompanied the principal investigator to offer advice on the trade and act as interpreter if required.

When tiger skeletons were presented for sale, the investigator verified the identity of the species by noting the presence of a distal foramen on the humerus. This is a feature unique to the Felidae and allows positive identification to the family level. There is no chemical test to distinguish tiger bone from other cat bones. Prior to the study the principal investigator examined tiger bones and teeth in the Smithsonian Museum of Natural History, which allowed easier identification of the skeletons, particularly if the skull was present. Tiger bones are larger than leopard bones, the only similar cat species in Indonesia, but because the range of leopards does not extend into Sumatra (Santiapillai and Ramono, 1992), and no information on leopard bones in trade in Indonesia has been recorded, it was assumed that all large cat bones that could be positively identified were tiger. Tiger teeth and claws were also presented for sale on numerous occasions, but the investigator could only judge the validity of this claim by assessing the general shape and size of the items. In one case, tiger-bone powder was offered for sale, but this could not be positively identified. Each seller was asked about the source of the bones, how long the seller had owned them, the asking price for the items (in Indonesian rupiah), and any information concerning other tiger-bone

Table 1. Summary of availability of tiger products in 88 retail outlets in northern Sumatra

\begin{tabular}{lcl}
\hline Town & Stores visited & Stores selling tiger products \\
\hline Medan & 9 TCM pharmacies & 1 selling bones and ground powder \\
Medan & 4 Western pharmacies & None found \\
Medan & 5 Jamu pharmacies & None found \\
Medan & 10 gold shops & 1 selling claws and teeth \\
Medan & 7 souvenir shops & 1 selling teeth \\
Kutacane & 4 gold shops & 1 selling teeth and claws \\
Blankejeren & Market stalls & No stalls found selling tiger parts \\
Blankejeren & 3 gold shops & 1 selling skin, teeth and bones; \\
& & 2 selling bones and teeth \\
Takengon & 5 gold shops & 1 selling bones and claws \\
Lawedeski & 4 gold shops & 1 selling bones (not seen) \\
Lawe Sigala & 3 gold shops & 1 with bones (not seen) \\
Subussalam & 4 gold shops & None found \\
Tapaktuan & 3 gold shops & None found \\
Sidikalang & 7 gold shops & 1 selling bones (not seen) \\
Kabanjahe & 15 gold shops & 1 selling claws and teeth \\
Pancur Batu & 1 gold shop & 1 selling teeth \\
Berastagi & 4 gold shops & None found \\
\hline
\end{tabular}

Notes: All products purporting to be tiger products were seen unless stated. See text for identification methods. The stores stated that the tiger teeth and claws being sold were genuine but these, although seen, could not be positively identified.

TCM, Traditional Chinese Medicine. 
suppliers or buyers. Prices quoted in this report are converted from rupiah to $\$ U S$ at the exchange rate at the time of the study of Rp2200/\$US 1 or the average rate at the previous time period in question. In order to avoid stimulating further tiger poaching no products were purchased during these visits. Skeletons were placed in a sack to be weighed using a spring balance. Some dealers or shops that had tiger bones were visited more than once.

\section{Results}

In Medan, four stores selling western-style medicines, five shops selling traditional Indonesian medicines ('jamu'), and nine Traditional Chinese Medicine (TCM) shops were visited to assess the availability of tiger bone or preparations containing it. Seven souvenir shops and 10 gold shops were also visited. Another 53 gold stores and one street market were visited in 11 towns around Gunung Leuser National Park in Aceh province (Table 1).

Of the 88 sites visited, only 10 (11 per cent) offered verified tiger products for sale, five had bones for sale and only one had a pelt for sale. None of the western pharmacies or shops selling Indonesian medicines, in either packaged or raw form, had any tiger bone or preparations containing tiger bone for sale. Only one Chinese pharmacy had tiger products on the premises, but this may be because none of the investigation team was or spoke Chinese rather than a lack of availability. The manager of this pharmacy claimed that tiger bone was also available in other TCM stores in Medan. While several gold-shop owners reported the use of rhino parts as a folk remedy by some non-Chinese Indonesians, jamu-shop owners maintained that traditional Indonesian medicines are generally restricted to plant materials.

Although tiger parts were seen in only one souvenir shop and one gold shop in Medan of the 17 visited, it became apparent from information obtained that gold shops were an important part of the tiger trade, so the study in the surrounding region focused on these outlets. Four gold shops in towns around Medan were willing to sell tiger bones, all of which were positively identified from the skull and humerus (Table 1).

The skeletons of nine tigers were observed: one at a TCM shop in Medan and eight in gold shops in Blankejeren and Takengon. Eight skeletons were weighed (Table 2). Stores wanted to sell only complete tiger skeletons, but the manager of the TCM pharmacy in Medan had sold a skull separately. He had, however, turned down a request to sell the humerus bones separately. These bones are considered to be the most medicinally potent by some Taiwanese (Mills and Jackson, 1994). The approximate age of the bones was determined using two methods. All the bones seen and identified were kept in unrefrigerated rooms adjacent to the shop. Because it would be difficult to keep bones fresh in these conditions, those bones that were yellowish, rather than off-white in colour, and covered in thin remnants of flesh were determined to be less than 1 year old. Additional information was obtained from the retailers.

In addition to the skeletons seen by the investigator, accounts were received about

Table 2. Weights of tiger bones for sale in Blankejeren and Takengon, south-east Aceh, Sumatra, Indonesia

\begin{tabular}{lll}
\hline Shop & $\begin{array}{l}\text { No. tigers } \\
\text { in sack }\end{array}$ & $\begin{array}{l}\text { Total weight } \\
\text { bones and sack } \\
(\mathrm{kg})\end{array}$ \\
\hline A & $2(1$ large/1 small $)$ & 10.00 \\
A & 1 & 2.25 \\
B & 1 & 3.50 \\
C & 1 & 6.25 \\
C & 1 & 8.25 \\
C & 1 & 4.25 \\
D & 1 & 3.50
\end{tabular}

Total wt. including sacks and straps $\quad 38.00$ Total wt. sacks and straps $(0.3 \mathrm{~kg} /$ sack $\times 6) \quad 2.10$ Total wt. tiger bones $\quad 35.90$

Average wt. bones/tiger (35.9/8 tigers)

Notes: shops A-C were in Blankejeren; shop D was in Takengon. 
approximately 22 other tigers whose bones were reported to be located throughout Aceh and northern Sumatra (Table 3). The TCM shop manager in Medan who owned the skeleton also claimed to have $100 \mathrm{~kg}$ of tiger bones, which had been ground into powder and already mixed into medicinal preparations. However, this mixture could not be positively identified.
Tiger teeth and claws were recorded for sale in seven gold shops (Table 1). The only nongold store that had tiger teeth or claws for sale was a souvenir shop in Medan. Farmers who take tigers, however, do not always sell these parts because some are kept as talismans to protect gardens from wild pigs. One of the six shops with tiger bones also had three tiger skins for sale, but the condition of these

Table 3. Summary of investigative reports of tigers poached in northern Sumatra

\begin{tabular}{lllllll}
\hline $\begin{array}{l}\text { Point } \\
\text { of sale }\end{array}$ & $\begin{array}{l}\text { Point } \\
\text { of capture }\end{array}$ & Province & $\begin{array}{l}\text { No. } \\
\text { tigers }\end{array}$ & $\begin{array}{l}\text { Wt. bones } \\
(\mathrm{kg})\end{array}$ & $\begin{array}{l}\text { Age bones } \\
\text { (years) }\end{array}$ & $\begin{array}{l}\text { Invest. } \\
\text { confirm }\end{array}$ \\
\hline $\begin{array}{lllll}\text { Medan } \\
\text { Medan }\end{array}$ & Unknown & N. Sumatra & $22^{*}$ & $100^{*}$ & $>1$ & $\begin{array}{l}\text { No } \\
\text { Pancur Batu }\end{array}$ \\
Kabanjahe & Gravey(?) & N. Sumatra & 1 & $?$ & $>1$ & Yes \\
Sidikalang & Unknown & N. Sumatra & 1 & $?$ & $?$ & No \\
Lawe Sigala & Unknown & S. E. Aceh & $4 ?$ & 16 & No & No \\
Lawedeski & Unknown & S. E. Aceh & $3 ?$ & 12 & $?$ & No \\
Takengon & Unknown & S. E. Aceh & 1 & 3.2 & 5 & Yes \\
Takengon & Unknown & S. E. Aceh & 1 & 4 & $<1$ & No \\
Takengon & Unknown & S. E. Aceh & 2 & $?$ & $>1$ & No \\
Takengon & Unknown & S. E. Aceh & 2 & 7.5 & $>1$ & No \\
Blankejeren & Mude & S. E. Aceh & $2 ?$ & 9 & $?$ & No \\
Blankejeren & Unknown & S. E. Aceh & 3 & 17.9 & $<1$ & Yes \\
Blankejeren & Unknown & S. E. Aceh & 4 & 14.8 & $>1$ & Yes \\
Kota Panjang & Unknown & S. E. Aceh & 1 & $?$ & 1 & No \\
Subussalam & Gelombang & C. Aceh & 4 & $?$ & $?$ & No \\
Truman & Truman & C. Aceh & 1 & 1.5 & $?$ & No \\
\hline
\end{tabular}

Total confirmed 9

Total estimated unconfirmed (skeletons) 22

Total estimated all reports 31

Total est. unconfirmed (bone powder*) 22

Total estimated all types $\quad 53$

Notes:

Point of sale, location where tiger bones were actually seen for sale or where information was received about bones for sale.

Point of capture, location where tiger bones were being kept by villager who supposedly caught tiger.

Province, province of point of sale. It may be, but is not necessarily, the same as the province for the point of capture.

No. tigers, number of tiger skeletons seen or estimated from the bone weight based on an average yield of 4.5 $\mathrm{kg}$ bone/tiger.

$\mathrm{Wt}$. bones, weight measured by investigators when possible or weight given by information source.

*, the $100 \mathrm{~kg}$ refers to a rough estimate of bone powder in storage, not bones in the whole form.

Age bones, estimated time when the seller either sold bones in his possession, acquired bones for potential sale, or time in the past the information source believed the catcher had acquired the bones. These times are consequently not comparable and should only be used to place actual capture time in a rough time frame. Invest. confirm., one or both members of the investigative team saw and confirmed the number of tiger skeletons for sale. In some of these cases, the weight of the bones was also recorded. 
suggested that they were not from freshly killed animals. A dealer in Takengon, who was not associated with a gold shop, occasionally procured tiger livers for their oil to treat skin ailments, but no evidence indicated that this product was being sold.

Table 4 presents the prices offered for tiger bones, claws and teeth. This shows that the retail price for tiger bones offered in the four shops to a non-Indonesian was consistent throughout the towns visited in northern Sumatra $(\operatorname{Rp} 10,000 / \mathrm{kg})$ and did not alter according to the type of store visited. Only one price at the poacher level was anecdotally recorded, that stated by a farmer to sell to an Indonesian trader $(\mathrm{Rp} 30,000 / \mathrm{kg})$. The dealers' prices showed more variation than retail prices. One dealer said he had sold bones in early 1995 to an Indonesian buyer for a gold store for Rp88,000/kg, compared with the lowest price recorded, $\mathrm{Rp} 15,000 / \mathrm{kg}$, sold by a trader to a gold shop in Kutacane. One export price was obtained. The manager of the TCM shop in Medan was selling whole skeletons for export for Rp250,000/ $\mathrm{kg}$ bones in 1993, but he said that the foreign buyer was no longer interested due to the increased restrictions on international trade in these items. This is the same price (equivalent to $\$ 125 / \mathrm{kg}$ at the exchange rates in 1993) paid by a South Korean importer to a Singaporean trading company for tiger bones shipped in mid-1993 (J. Gavitt, pers. comm.).

The retail price recorded for tiger teeth and claws showed greater variation than that for bones. The price for a single tiger canine ranged from Rp75,000 to Rp150,000, the latter quoted in Medan where it is expected that prices would be higher. Claws were offered at prices varying from Rp5000 each to Rp35,000, dependent on size. Teeth and claws were sometimes displayed in custom-designed gold

Table 4. Prices quoted for tiger parts

\begin{tabular}{llll}
\hline Part & Stage of the trade & Place & Equivalent $\$$ US price \\
\hline Bones & Hunter & Pancur Batu & $\$ 13.60 / \mathrm{kg}^{*}$ \\
Bones & Dealer & Subussalam & $\$ 6.80 / \mathrm{kg} \dagger$ \\
Bones & Dealer & Takengon & $\$ 40.00 / \mathrm{kg} \ddagger$ \\
Bones & Dealer & Blankejeren & $\$ 18.20 / \mathrm{kg} \$$ \\
Bones & Retail (gold store) & Blankejeren & $\$ 45.45 / \mathrm{kg}$ \\
Bones & Retail (gold store) & Lawedeski & $\$ 45.45 / \mathrm{kg}$ \\
Bones & Retail (gold store) & Lawe Sigala & $\$ 45.45 / \mathrm{kg}$ \\
Bones & Retail (TCM store) & Medan & $\$ 45.45 / \mathrm{kg}$ \\
Bones & Export value & Medan & $\$ 125.00 / \mathrm{kg} \mathbb{I}$ \\
Claws & Retail (gold store) & Takengon & $\$ 2.27$ each \\
Claws & Retail (gold store) & Blankejeren & $\$ 7.50$ each \\
Small claws & Retail (gold store) & Medan & $\$ 11.36$ each \\
Large claws & Retail (gold store) & Medan & $\$ 15.91$ each \\
Canine tooth & Retail (gold store) & Medan & $\$ 68.18$ each \\
Canine tooth & Retail (gold store) & Kutacane & $\$ 45.45$ each \\
Canine tooth & Retail (gold store) & Blankejeren & $\$ 34.09$ each \\
\hline
\end{tabular}

* Price quoted by a farmer to sell to a gold store buyer.

+ Price stated by a dealer who sold bones to a gold shop buyer.

$\ddagger$ Price stated by a trader who sold a consignment to an Indonesian buyer.

$\S$ Price stated by a trader who was offered bones from an Indonesian seller.

II Price quoted by a former exporter of bones from Indonesia.

The prices shown were quoted to the investigator for products seen except for those listed above, which were prices stated as being offered or sold to other individuals.

All prices were offered or quoted in rupiahs, and converted at the exchange rate then of Rp22,000: \$US1. The price of the bones marked with * was converted at the exchange rate of the time, Rp2000: \$US1. 
pendants. No prices were obtained for tiger skins.

Identifying the source of tiger parts was more problematic. Although several tiger-part retailers in Kutacane identified Blankejeren at the north end of Gunung Leuser National Park as the source of items such as claws and teeth, sellers seldom provided specific information regarding the source of their tiger bones. No reports were heard of professional poachers hunting tigers, and the retailers stated that all the animals recorded in this study were killed by farmers. Gold-shop owners provided two versions of how tigers were hunted by villagers. The first method involved placing poison on a farm animal already killed by the tiger, in preparation for it returning for a second meal. However, because the tiger invariably returned to the forest to die, marketable parts could only be taken if the body could be located. Tiger poisoning has been reported elsewhere in Indonesia and Nepal (Martin, 1992; Tilson et al., 1994). The second method involved placing snares on the outskirts of the fields, primarily to catch wild pigs, but also occasionally taking tigers. There are other reports of tigers being caught deliberately or accidentally in snares in Indonesia and Thailand (Tilson et al., 1994).

Once a farmer had tiger parts for sale, he would sell them directly to local gold shops or to traders and dealers who passed through the villages. The traders would buy tiger teeth or claws, in particular, along with antique handicrafts in exchange for cash or gold. Traders then sold the tiger parts to gold shops in towns or cities. Gold-shop owners sometimes kept tiger bones in storage for several months or years before someone from a larger city came to buy them. According to the owners, these buyers were often ethnic Chinese. The manager of the TCM pharmacy in Medan, however, stated that he obtained tiger bones from a seller and not via other gold shops.

Tiger-part retailers were aware that the practice was illegal, but did not express concern that the authorities would interfere with either the sale or transport of these materials. This contrasted with their concern and suspicion if enquiries were made about the availability of rhinoceros products. Only one Sumatran rhino Dicerorhinus sumatrensis horn and one hoof were recorded. Tiger bones were usually kept in back rooms, but several gold stores had tiger teeth and claws openly displayed in their store windows. In addition to tiger parts, parts of other endemic species were recorded in the visits to the TCM shop in Medan and gold shops in the surrounding towns.

\section{Discussion}

No evidence was found showing that there is organized poaching for tigers for trophy mounts or for the international trade in bones used in oriental medicine. However, it is apparent that many tigers that are killed opportunistically or deliberately by farmers are being fed into a commercial domestic market for tiger bones, teeth, claws and skins. This is centred on the gold shops in the main communities in Sumatra. The fact that the main suppliers of this market are farmers and the trapping methods reported suggest that tiger poaching occurs on the edge of protected areas, where potential conflict exists between the tiger and domesticated animals.

Estimating the effect of this trade on the tiger population in Sumatra is difficult. This is partially because of the lack of accurate recent data on the population and the lack of previous studies on tiger poaching in Sumatra. It was also difficult to obtain information on the sources of the bones, which could be from animals held in private collections as well as those in the wild. However, some tentative conclusions can be drawn by using the information that is available. Between 1988 and 1992 , official figures estimated that six tigers were poached annually from the wild populations around the five national parks (Tilson and Traylor-Holzer, 1994). The data presented in this study indicate that in the sample of shops visited in northern Sumatra alone, the skeletons and bones of five recently killed tigers were found. In addition, the existence of five other skeletons from freshly killed 
animals and the bones of others were reported.

Chinese TCM shops were not adequately surveyed, but were reported as being a retail outlet for tiger-bone preparations. Nor was a survey conducted in the towns of southern Sumatra. For these reasons, the number presented here is undoubtedly a minimum and the total number of tigers that are poached annually in Sumatra for the internal bone trade seems to be higher than previous figures suggested.

In addition, tigers are removed from the wild for three other reasons. The Indonesian Department of Forest Protection and Nature Conservation estimated that six problem animals' were removed per year in the period 1988-92, but this figure may have since declined to only four in total for the period 1992-95 (R. L. Tilson, pers. comm.). The numbers of tigers removed historically or recently for taxidermic mounts or for the international bone trade are unknown. However, exports of tiger bones from Indonesia were recorded in South Korean customs statistics from 1973 to 1992 (Mills and Jackson, 1994) and in 1992 1081 permits for mounted tigers were reportedly issued in the Indonesian amnesty.

Even without these four pressures, the Sumatran tiger's core population of 400-650 animals split into more than five subpopulations would make it a critically endangered subspecies. Efforts by Indonesian authorities to establish protected forest areas certainly provide a key cornerstone toward tiger conservation (Ashby and Santiapillai, 1987). Only the 400 animals contained in the five national parks represent potentially viable subpopulations (Tilson et al., 1994). The increase in efforts to urge village people to co-operate with forest agency personnel in dealing with problem tigers through non-lethal means is also important, particularly because this study indicates that farmers are probaly the main hunters of tigers in Sumatra.

The tiger's possible saving grace in Sumatra is that it seems to have a robust ability to survive in marginal habitats and strong reproductive potential (Seal et al., 1992). However, unless specific action is taken to control poaching by removing the commercial incentives for killing tigers, existing efforts alone will not be sufficient to safeguard the future for wild populations of Sumatran tigers (Jackson, 1993). Even allowing that a portion of the bones may have come from animals bred in captivity, the numbers killed for the domestic trade described in this study suggests that the internal market is a real threat to the future of the Sumatran tiger.

\section{Acknowledgements}

Special thanks are due to members of the Friends of Leuser Park who provided invaluable help during the fieldwork, and to Megaharianto and Ramon Jenis from the Indonesian Department of Forest Protection and Nature Conservation, Michael Griffiths from the Leuser Development Programme, Anjar and Musnardi from WWF-Indonesia, who provided assistance in the field. Ronald Tilson from the Minnesota Zoo and Peter Jackson, Chair of the IUCN Cat Specialist Group, gave useful help and guidance on the conservation status and threats to the Sumatran tiger, and made useful comments on an earlier draft. Linda Gordon and staff of the Smithsonian Museum of Natural History made the tiger-bone collection of the Museum available and assisted in identification aids, Theodore Grand of the National Zoo, Dorene Bolze and staff of the Wildlife Conservation Society also greatly assisted various phases of this project. The fieldwork for this study was undertaken under a grant provided by the Delano Foundation, USA.

\section{References}

Ashby, K.R. and Santiapillai, C. 1987. An outline strategy for the conservation of the tiger (Panthera tigris) in Indonesia. In Tigers of the World (eds R. L. Tilson and U.S.Seal), pp. 85-91. Noyes Publications, Park Ridge, NJ, USA.

Borner, M. 1978. Status and conservation of the Sumatran tiger. Carnivore, 1 (1), 97-102.

Jackson, P. 1993. The Status of the Tiger in 1993. Report of Cat Specialist Group, Species Survival Commission, IUCN, Gland, Switzerland.

Martin, E.B. 1992. The poisoning of rhinos and tigers in Nepal. Oryx, 26, 82-86.

Mills J.A. and Jackson, P. 1994. Killed for a Cure: A Review of the Worldwide Trade in Tiger Bone. TRAFFIC International, Cambridge, UK.

Santiapillai, C. and Ramono, W.S. 1987. Tiger numbers and habitat evaluation in Indonesia. In Tigers of the World (eds. R. L. Tilson and U. S. Seal), pp. 
85-91. Noyes Publications, Park Ridge, NJ, USA.

Santiapillai, C. and Ramono, W.S. 1992. Status of the leopard (Panthera pardus) in Java, Indonesia. Tiger Paper, 19 (2), 1-5.

Santiapillai, C. and Ramono, W.S. 1993. Conservation of Sumatran tiger (Panthera tigris sumatrae) in Indonesia. Tiger Paper, 20, 44-48.

Seal, U., Soemarna, K. and Tilson, R.L. 1992. Population Biology and Analyses for Sumatran Tiger. PHVA Report. Unpubl.

Tilson, R.L., Soemarna, K., Ramono, W., Lusli, S., Traylor-Holzer, K. and Seal, U.S. (eds) 1994. Sumatran Tiger Population and Habitat Viability Analysis Report. Indonesian Department of Forest Protection and Nature Conservation (PHPA) and
IUCN/SSC Captive Breeding Specialist Group, Jakarta and Apple Valley, MN, USA.

Tilson, R.L. and Traylor-Holzer, K. 1994. Estimating poaching and removal rates of tigers in Sumatra. In Sumatran Tiger Population and Habitat Viability Analysis Report (eds R. L. Tilson et al.), pp. 39-44. PHPA and IUCN/SSC, Jakarta and Apple Valley, MN, USA.

WWF Indonesia. 1992. Sustainable use of wildlife: the key to preventing further species declines in Indonesia. Conservation Indonesia, 65 (3), 213-217

Campbell Plowden and David Bowles, Environmental Investigation Agency, 15 Bowling Green Lane, London EC1R 0BD, UK. 